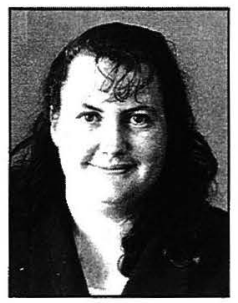

\title{
EDUCATION AND TRAINING IN THE LABOUR FORCE
}

\author{
Raewyn O'Neill \\ Statistics New Zealand
}

\begin{abstract}
In their 1997 green paper on tertiary education the Ministry of Education said, "to ensure our prosperity New Zealand needs to be a 'learning society' recognising the importance for all of our people to continue to develop new skills and knowledge throughout a person's lifetime." Given the importance of an educated and adaptable workforce, there is suprisingly little information available on education and training undertalen in New Zealand. While some information is collected on those enrolled in study towards formal education qualifications, there is little available information on human capital development beyond this. One of the few sources of information is the Education and Training Survey (ETS), conducted in September 1996. This paper uses information collected in the ETS to look at the characteristics of those participating in education and training as well as the barriers to and reasons for participation in education and training. It then goes on to compare the labour market outcomes of those people who participated in education and training with those who did not.
\end{abstract}

Keywords: education, training, human capital

The skills of the labour force are an influencing factor in the growth of a country's productivity. A report from the Organisation for Economic Co-operation and Development $(\mathrm{OECD})^{1}$ published in 1996 suggested that the low productivity growth in New Zealand during the 1980's could be a result of the relatively low vocational skills of the labour force. More recently, the Ministry of Education's 1997 green paper on tertiary education included the comment that "To ensure our prosperity New Zealand needs to be a 'learning society' recognising the importance for all of our people to continue to develop new skills and knowledge throughout a person's lifetime.".2

Analysis by overseas researchers (eg. Lynch, 1995) has shown that for the individual, participation in education and training can enhance their work skills, reduce their probability of becoming unemployed, and increase their earnings potential. Increased education and training has been acknowledged as one of the solutions to wage inequality. ${ }^{3}$

However, in New Zealand, there is surprisingly little information and analysis available on education and training particularly given the importance that has been placed on having an educated and adaptable workforce. Some information is collected from those enrolled in study towards formal educational qualifications, including vocational qualifications. The five yearly Population Census enables some analysis of the income differentials for those with qualifications (for example Maani 1998). There is, however, little available information on other forms human capital development.
One of the few sources of information on education and training is the Education and Training Survey (ETS), conducted in the September 1996 quarter. This is the only survey of this kind ever to be conducted in New Zealand. The ETS was conducted as a supplement to the Household Labour Force Survey (HLFS). All respondents participating in the HLFS and between 15 and 64 years of age were eligible to respond to the ETS. The sample size of the ETS was approximately 22,250 people.

The ETS asked people about their participation in education and employment-related training in the 12-months immediately prior to the survey date. Amongst other subjects, information was collected on the reasons for participation in education and training, the barriers to education and training, and expected outcomes from undertaking education and training. This survey provides a useful insight into the characteristics of those who did and did not participate in education and training.

This paper uses information from the ETS to explore these aspects of education and training in more detail. Unless otherwise stated this analysis looks only at the labour force; that is, people who were either employed or unemployed in the week before they were surveyed. Focusing only on the labour force allows the analysis to look specifically at the impact of education and training on the individual's labour market status. The labour force status ${ }^{4}$ used in this analysis is that of the respondent at the time they were surveyed, while the education and training discussed is that undertaken in the twelve months prior to the time the re- 
- An educational qualification is defined as an award for attainment of a formally recognised qualification from a recognised provider. It equips the learner with skills or knowledge that can be identified in terms of the standard attained and the field to which it relates. A formally recognised qualification is one which is assessed under the auspices of the New Zealand Qualifications Authority (NZQA) or awarded overseas by a recognised authority.

- In-house training is that organised by an employer primarily to meet the needs of its own employees, is conducted in-house or externally, and is delivered by the company's own employees or external training providers.

- External training covers all other employment-related training for the employed and unemployed.

spondent was interviewed. Therefore, it is possible that the individual's labour force status may have changed between participating in education and training and completing the survey.

The first section of this paper looks at the characteristics of those participating in education and training, while the second section looks at the difficulties that prevent people from participating in education and training and the support provided for some participants. Finally, this paper discusses people's reasons for participation and provides some insights into the labour market outcomes from participation in education and training.

\section{Characteristics of education and training participants}

The ETS tells us that 42.2 percent of the labour force, or approximately 752,300 people, were involved in education and training in the year to the September quarter 1996. The participation rate for the employed was slightly higher than that for the unemployed; 42.5 and 37.0 percent respectively. There were also differences in the education and training participation rates by sex with 40.4 percent of males and 44.4 percent of females participating in education and training. These results are shown in Table 2.

The ETS tells us that education and training involved just under half of the labour force, or approximately 752,300 people, in the year to the September 1996. The participation rate for the employed was slightly higher than that for the unemployed; 42.5 and 37.0 percent respectively. There were also differences in the education and training participation rates for males and females with 40.4 and 44.4 percent respectively.

An estimated 13.6 percent of the labour force (or 232,700 people) were involved in some form of study towards an

Table 2. Participation in education and training in previous 12 months for the labour force

\begin{tabular}{lccr}
\hline & Employed & $\begin{array}{c}\text { Labour Force } \\
\text { Unemployed } \\
(000 \text { s })\end{array}$ & Total \\
\hline Studying a qualification & 213.9 & 18.8 & 232.7 \\
Not studying a qualification & 1398.5 & 83.5 & 1482.0 \\
Still at school & 60.1 & 8.5 & 68.6 \\
Total & 1672.5 & 110.9 & 1783.3 \\
\hline Participating in in-house & 337.5 & 3.7 & 341.2 \\
Not participating in in-house & 1335.0 & 107.1 & 1442.1 \\
Total & 1672.5 & 110.9 & 1783.3 \\
\hline Participating in external & 238.0 & 15.2 & 253.2 \\
Not participating in external & 1434.5 & 95.6 & 1530.1 \\
$\quad$ Total & 1672.5 & 110.9 & 1783.3 \\
\hline Total participating in education & 711.2 & 41.0 & 752.3 \\
or training & & 69.8 & 1031.1 \\
Total not participating in & 961.3 & & \\
education or training & 1672.5 & 110.9 & 1783.3 \\
$\quad$ Total & & & \\
\hline
\end{tabular}

Source: Statistics New Zealand Education and Training Survey 
educational qualification, (as defined in Table 1), in the year ended September 1996. This excludes those still at school. Meanwhile, 19.1 percent of the labour force (341,200 people) participated in in-house training and 14.2 percent $(253,200$ people) participated in external training. Note that people could participate in more than one form of education or training over the 12 -month period.

This section incorporates multivariate and cross sectional analysis to look at the characteristics of participants in education and training in more detail.

\section{Methodology $\mathbf{y}^{5}$}

A logistic regression model was fitted for each of the three types of education and training, as well as one to explain the likelihood of an individual studying towards a qualification full-time or part-time. The explanatory variables input to the model were collapsed into dichotomous (or binary) responses to reduce the complexity of the data, and as an aid to interpretation.

Two important binary splits were the grouping of occupation and industry. Each was split into two groups. The two occupation groups are aggregations of the New Zealand Standard Classification of Occupation 1995 (NZSCO95). The 'managerial/professional' group includes legislators, administrators and managers; professionals; and technicians and associate professionals. The 'clerical/trades' group includes all other occupations, namely clerks; service and sales workers; agriculture and fishery workers; trades workers; plant and machine operators and assemblers; and elementary occupations.

The industry classification was split in a similar manner, using the New Zealand Standard Industrial Classification 1987 (NZSIC87). The 'service' industries group includes wholesale and retail trade, restaurants and hotels; transport, storage and communication; business and financial services; and community, social and personal services. The 'production' industry group includes agriculture, hunting, forestry and fishing; mining and quarrying; manufacturing; electricity, gas and water; and construction. Throughout the rest of this paper, industry and occupational groups are referred to using the above names.

\section{Educational qualifications}

Table 3 contains the coefficients and significance for the explanatory variables in the first logistic regression model fitted.

The equation shows that participants in study towards an educational qualification were most likely to be studying for their first qualification, be under 30 and have one or more years of post-school education. This is not surprising as it supports Census data showing that only a small proportion of the population has more than one qualification. The traditional pattern of moving from school to study for another educational qualification would explain why there are very high participation rates for those under 30 . The highest participation rate was for those in the 20-24 years age group, with 36.1 percent studying towards some form of qualification.

The most common qualification level to be working towards also differed by age. Of those aged 15-19 years, the most common post-school education qualification was a bachelor degree, studied for by 7.0 percent of the labour force. In the 20-24 years age group, 17.4 percent of the labour force were studying towards a bachelor degree. The most common qualification studied for by members of the labour force between 25 and 54, was an advanced vocational qualification. For example, an undergraduate diploma/certificate, New Zealand Certificate, or a national diploma, 31,500 people or 1.7 percent of the labour force were studying for this qualification.

Age is also useful in explaining the result in table three which implies that those in the New Zealand Maori and Pacific Island ethnic groups were 1.3 times more likely to participate in study towards an educational qualification. The survey tells us that 44.7 percent of the labour force in the New Zealand Maori and Pacific Island ethnic groups were between 15 and 29 years of age. This can be compared with 30.6 percent of those in the New Zealand European/Pakeha ethnic group in this age group. Therefore, the apparent difference may be a reflection of their differing age structures.

The first regression equation also showed that participants in study towards an educational qualification were more likely to be working part-time (fewer than 30 hours per week) and have been with their current employer for fewer than five years. This is most likely because a large number of students find part-time work to support themselves while they are studying.

For the second logistic regression the focus was on the probability of someone studying full time towards an educational qualification, as opposed to studying part time. The details of this regression equation are shown in Table 4.

Results from this regression are consistent with results from the first regression model fitted. Those in the labour force under 30 years of age were 6.0 times more likely than those aged 30 years or over to have studied full time for an educational qualification in the year to September 1996. Not surprisingly, part-time workers were 5.2 times more likely to be engaged in full time study than full-time workers.

\section{In-house training}

Unlike study towards an educational qualification, the third logistic regression model showed that people who had been with their current employer for five or more years were 1.2 times more likely to have participated in in-house training than those who had been in the same position for less than five years. As shown in Table 5, those people earning more than $\$ 39,000$ per year were 1.6 times more likely to have participated in in-house training than people earning $\$ 39,000$ or less. 


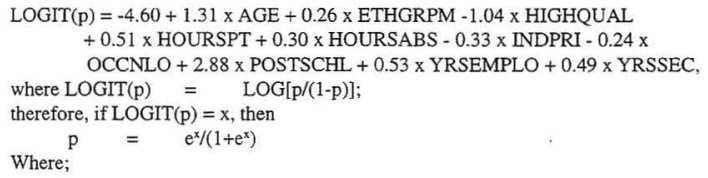

INDPRI $=0=$ "Not production industries"

YRSEMPLO $=1$ = Less than 5 years with current employer'; YRSEMPLO $=0=$ ' 5 or more years with current employer'

YRSSEC $=1=$ ' 4 years or more secondary education';

Higher salaries normally accompany age and experience, so it is not unexpected that people aged 30 years and over were 1.4 times more likely to have participated in in-house training than those in the younger age group. Full-time employees were also more likely to have participated in in-house training than part-time employees.

Approximately 60.6 percent of full-time employees were employed in the clerical/trades occupation group, according to the 1996 Census. Employees in these occupations were over twice as likely to have participated in in-house training than those in the managerial/professional occupation group. Additionally, the clerical/trades occupation group employed 63.7 percent of all female employees and female employees were 1.3 times more likely to participate in in-house training than male employees.

One interesting result from this regression was that a person from outside the Auckland, Wellington and Christchurch regional council areas was 1.2 times more likely to participate in in-house training than someone from a major urban area, although the limitations of the analysis precluded a more detailed examination across a wide range of geographical areas. It is possible that this regional variation in training is due to the different industry make up of the regions. 
People born in New Zealand were 1.2 times more likely to participate in in-house training than those born outside of New Zealand.

\section{External training}

External training includes employees, the self-employed and the unemployed. This has had an impact on the number of significant variables in the regression equation, as shown in Table 6. However, the employed still made up the vast majority of people who did external training ( 94.0 percent or 238,000 people) and therefore had the biggest influence on the regression results.

Amongst those in employment, people employed in the service industry group were 1.4 times more likely to have participated in external training than those in the production industry group. The service industry group was the largest industry group at the time of the 1996 Census, accounting for $1,032,156$ people or 67.5 percent of the employed.

As with in-house training, females were 1.3 times more likely than males to attend external training.

\section{Barriers and support for education and training}

\section{Barriers}

People may be prevented from participating in education and training for a number of reasons. The ETS asked respondents if there were any courses they wanted to go on to improve their job skills - but didn't, and if so, what prevented them from going on that course. Respondents were asked to select as many barriers as were relevant from a list including: 'time', 'cost', 'transport or location', 'disability', 'childcare', 'other family responsibilities', 'lack of employer support', 'lack of English', 'other', and 'no difficulty'.

Just over one-third ( 34.0 percent) of the unemployed said that there was a course they wanted to do to improve their job skills but did not, while slightly less of the employed (24.3 percent) had courses they would like to have participated in. The most common barrier for these people was 'time', selected by 249,700 people, or 56.2 percent. One or both of 'childcare' or 'other family responsibilities' were selected as barriers by 15.7 percent of those who desired education or training. This is shown in Table 7.

\section{Table 4. Logistical regression: full-time study towards an educationl qualification}

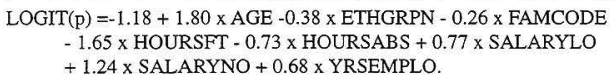

\begin{tabular}{|c|c|c|c|}
\hline Variable & $\begin{array}{l}\text { Chi-square } \\
\text { Statistic }\end{array}$ & p-value & Odds ratio \\
\hline
\end{tabular}

$\mathrm{AGE}=1=$ ' 15 to 29 years'

362.0

0.0001

$\mathrm{AGE}=0=$ ' 30 years or over'

HOURSFT $=1=$ ' 30 or more hours per week' 


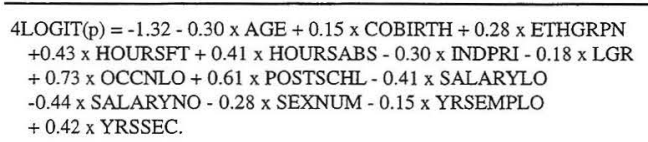

\begin{tabular}{|c|c|c|c|}
\hline Variable & $\begin{array}{c}\text { Chi-Square } \\
\text { Statistic }\end{array}$ & p-value & Odds ratio \\
\hline $\begin{array}{l}\text { OCCNLO }=1=\text { 'Clerks/ trades, occupation group' } \\
\text { OCCNLO }=0=\text { 'Not } \text { clerks/trade occupation group' }\end{array}$ & 1000.8 & 0.0001 & 1.3 \\
\hline $\begin{array}{l}\text { POSTSCHL }=1=\text { 'One or more years of post-school education' } \\
\text { POSTSCHL }=0=\text { 'Zero years post-school education' }\end{array}$ & 295.4 & 0.0001 & 1.7 \\
\hline $\begin{array}{l}\mathrm{AGE}=1=\text { ' } 15 \text { to } 29 \text { years' } \\
\mathrm{AGE}=0=\text { ' } 30 \text { years or over' }\end{array}$ & 80.7 & 0.0001 & 0.71 \\
\hline $\begin{array}{l}\text { YRSSEC }=1=\text { ' } 4 \text { years or more secondary education' } \\
\text { YRSSEC }=0=\text { 'Less than } 4 \text { years secondary education' }\end{array}$ & 70.9 & 0.0001 & 1.7 \\
\hline $\begin{array}{l}\text { INDPRI }=1=\text { 'Primary and secondary industries' } \\
\text { INDPRI }=0=\text { 'Not primary and secondary industries" }\end{array}$ & 45.5 & 0.0001 & 0.71 \\
\hline $\begin{array}{l}\text { ETHGRPN }=1 \text { = 'New Zealand European/Pakeha' } \\
\text { ETHGRPN }=0=\text { 'Maori/Pacific islands ethnic groups' }\end{array}$ & 45.3 & 0.0001 & 1.3 \\
\hline $\begin{array}{l}\text { HOURSFT }=1=\text { ' } 30 \text { or more hours per week' } \\
\text { HOURSFT }=0=\text { 'Not } 30 \text { or more hours per week' }\end{array}$ & 35.4 & 0.0001 & 1.5 \\
\hline $\begin{array}{l}\text { SEXNUM }=1=\text { 'Male' } \\
\text { SEXNUM }=0=\text { 'Female' }\end{array}$ & 33.8 & 0.0001 & 0.77 \\
\hline $\begin{array}{l}\text { SALARYLO }=1=` \$ 39,000 \text { or less' } \\
\text { SALARYLO }=0=\text { 'More than } \$ 39,000 ’\end{array}$ & 32.2 & 0.0001 & 0.66 \\
\hline $\begin{array}{l}\text { HOURSABS }=1=\text { 'Absent due to illness, holiday, etc.' } \\
\text { HOURSABS }=0=\text { 'Not absent due to illness, holiday, etc.' }\end{array}$ & 28.9 & 0.0001 & 1.5 \\
\hline $\begin{array}{l}\text { LGR }=1=\text { 'Major urban' } \\
\mathrm{LGR}=0=\text { 'Minor urban and rural' }\end{array}$ & 21.6 & 0.0001 & 0.83 \\
\hline $\begin{array}{l}\text { SALARYNO }=1=\text { 'Not working for salary \& wages' } \\
\text { SALARYNO }=0=\text { 'Working for salary \& wages' }\end{array}$ & 12.0 & 0.0005 & 0.63 \\
\hline $\begin{array}{l}\text { YRSEMPLO }=1=\text { 'Less than } 5 \text { years with current employer' } \\
\text { YRSEMPLO }=0=\text { 'Not less than } 5 \text { years with current employer' }\end{array}$ & 11.4 & 0.0007 & 0.83 \\
\hline $\begin{array}{l}\operatorname{COBIRTH}=1=\text { 'Born in New Zealand' } \\
\operatorname{COBIRTH}=0=\text { 'Born overseas' }\end{array}$ & 6.9 & 0.0085 & 1.2 \\
\hline
\end{tabular}


SLOGIT(p) $=-2.27+0.23 \times$ ETHGRPN $-0.32 \times$ INDPRI $+0.26 \times$ OCCNLO $+0.54 \times$ POSTSCHL $-0.41 \times$ SALARYLO $-0.26 \times$ SEXNUM + $0.55 \times$ YRSSEC.

\begin{tabular}{|c|c|c|c|}
\hline Variable & $\begin{array}{l}\text { Chi-Square } \\
\text { Statistic }\end{array}$ & p-value & Odds ratio \\
\hline $\begin{array}{l}\text { YRSSEC }=1=\text { ' } 4 \text { years or more secondary education' } \\
\text { YRSSEC }=0=\text { 'Less than } 4 \text { years secondary education' }\end{array}$ & 121.4 & 0.0001 & 1.7 \\
\hline $\begin{array}{l}\text { POSTSCHL }=1=\text { 'One or more years of post-school education' } \\
\text { POSTSCHL }=0=\text { 'Zero years post-school education' }\end{array}$ & 58.8 & 0.0001 & 1.7 \\
\hline $\begin{array}{l}\text { OCCNLO }=1=\text { 'Clerks } / \text { trades, occupation group' } \\
\text { OCCNLO }=0=\text { 'Not clerks/trade occupation group' }\end{array}$ & 25.4 & 0.0001 & 1.3 \\
\hline $\begin{array}{l}\text { INDPRI }=1=\text { 'production industry group' } \\
\text { INDPRI }=0=\text { 'Not production industry group' }\end{array}$ & 19.6 & 0.0001 & 0.71 \\
\hline $\begin{array}{l}\text { SALARYLO }=1=\text { = } \$ 39,000 \text { or less' } \\
\text { SALARYLO }=0=\text { 'More than } \$ 39,000 \text { ' }\end{array}$ & 15.0 & 0.0001 & 0.67 \\
\hline $\begin{array}{l}\text { SEXNUM }=1=\text { 'Male' } \\
\text { SEXNUM }=0=\text { 'Female' }\end{array}$ & 12.7 & 0.0004 & 0.77 \\
\hline $\begin{array}{l}\text { ETHGRPN }=1=\text { 'New Zealand European/Pakeha'; } \\
\text { ETHGRPN }=0=\text { 'Maori } / \text { Pacific Islands ethnic groups' }\end{array}$ & 5.0 & 0.0252 & 1.3 \\
\hline
\end{tabular}

Source: Statistics New Zealand Education and Training Survey

For those who did participate, the biggest barrier that people studying towards an educational qualification had to overcome was 'time', selected by 95,900 people ( 41.2 percent of participants). Other significant barriers for people studying towards an educational qualification were 'cost', selected by 86,000 people ( 37.0 percent); and 'transport or location', selected by 36,500 people or 15.7 percent of those studying towards an educational qualification. 'Childcare' and 'other family responsibilities' were selected as barriers by 9.4 and 13.9 percent of female participants respectively. One-third of participants in education, or 78,500 people, said that they had 'no difficulty'.

Given that in-house training is provided by the employer and often in work time, it is not surprising that there were relatively few barriers selected by participants, with 260,300 people (76.3 percent) selecting 'no difficulty'. 'Cost' was selected as a barrier by 12,600 people, or 3.7 percent of inhouse training participants. 'Time' was the most commonly selected barrier to in-house training, selected by 50,400 people or 14.8 percent of participants.

'Childcare' and 'family responsibilities' were selected less often as barriers for in-house training participants (6.2 and 4.7 percent respectively). This could be due to the different characteristics of in-house training participants, discussed previously, or perhaps because most in-house training is conducted during work time, when childcare arrangements have already been made.

External training participants also had relatively few barriers, with 154,100 people, or 60.9 percent, having no difficulty attending. For those who did select barriers, 59,700 people (23.5 percent) selected 'time' while 'cost' was selected by 29,000 people or 11.4 percent of participants. The high proportion of employed participants in external training is reflected in the relatively low proportion of people who had difficulty participating. As with in-house training, this was because they were receiving support from their employers.

\section{Support}

For some people, participation in education and training was made much easier by employer support. The level of support provided by employers for participation in education and external training varied by salary, occupation, length of time with the employer and whether it was education or external training. In-house training is provided by the employer, and therefore, by definition the employee is supported to attend. While it is possible that demographic characteristics may also have had an impact on support for education and training, these are not covered in this paper. 
Table 7. Barriers to participation in education and training

\begin{tabular}{|c|c|c|c|c|}
\hline Difficulty & Education Study & $\begin{array}{l}\text { In-house Training } \\
(000 s)\end{array}$ & External Training & Courses Desired \\
\hline Time & 95.9 & 50.4 & 59.7 & 249.7 \\
\hline Cost & 86.0 & 12.6 & 29.0 & 200.9 \\
\hline Transport or location & 36.5 & 17.7 & 25.1 & 51.6 \\
\hline Disability & 4.4 & 2.6 & 2.3 & 4.9 \\
\hline Childcare & 14.1 & 11.8 & 11.7 & 38.3 \\
\hline Other family responsibilities & 27.3 & 12.3 & 14.5 & 45.0 \\
\hline Lack of employer support & 7.3 & 4.1 & 2.7 & 43.4 \\
\hline Lack of English & 2.0 & 1.0 & 1.8 & 3.0 \\
\hline Other & 6.9 & 4.5 & 3.3 & 72.0 \\
\hline Total & 280.6 & 116.9 & 150.2 & 708.9 \\
\hline At least one of the above & 152.6 & 79.0 & 93.3 & 440.8 \\
\hline No difficulty & 78.5 & 260.3 & 154.1 & 2.5 \\
\hline Still at school & 68.6 & N/A & N/A & N/A \\
\hline Not specified & 1.6 & 1.9 & 5.8 & 0.4 \\
\hline No courses desired & N/A & N/A & N/A & 1339.7 \\
\hline Not participating & 1482.0 & 1442.1 & 1530.1 & N/A \\
\hline Total & 1783.3 & 1783.3 & 1783.3 & 1783.3 \\
\hline
\end{tabular}

Source: Statistics New Zealand Education and Training Survey

There was a relationship between the amount of support provided by the employers and the salary of participants involved in study towards an educational qualification. Just 14.0 percent of those earning under $\$ 14,000$ received support from their employer, and the majority of hat support was 'payment for fees or materials'. At the other end of the salary scale, 69.0 percent of those whose annual salary was over $\$ 39,000$ received support to study. The most common support provided in this situation was also 'payment for fees or materials'.

Length of time with the employer showed a similar trend. Amongst those wage and salary earners who had been with their employer less than 6 months, just 14.5 percent received support. In comparison, 64.3 percent of those who had been with their employer 10 years or more received support.

'Payments for fees or materials' were made by employers for 20.0 percent of people who had been with their firm for fewer than six months and were studying towards an educational qualification. The proportion of employees receiving support increased with the length of time with the employer. The majority of those studying who had been with their employer for five years or more received assistance through either 'payment for fees and materials' or 'paid leave' from work.

In the case of external training, the most common type of support from employers was 'payment for fees or materials' or 'paid leave'. Unlike study for educational qualifications the length of time the employee had been with the firm did not have a significant effect on the amount of support external training participants received. However, salary did have a significant effect on the amount of support, with 88.0 percent of those earning over $\$ 39,000$ receiving support, compared with 39.9 percent of those earning under $\$ 14,000$. This may be a reflection of the earlier finding that part-time employees are less likely to participate in external training.

\section{Section Three - labour market outcomes from education and training}

\section{Reasons for participation in education and training}

Participation in education and training may last for more than one year, particularly for study towards a qualification. For this reason it was not possible to ask people what happened as a result of participation in education and training in the ETS. However, respondents were asked about their reasons for participating. In addition, all respondents regardless of their participation in education and training, were asked about their expected training and labour market outcomes in the following 12 -months. Non-participants were asked their opinion on the labour market outcomes of education and training. Respondents were asked to select as many answers as applicable from a list of: 'further training or qualifications', 'get a job or a different job', 'improve job skills', 'different tasks in job', 'pay rise or promotion', and 'none of the above'.

The majority of the labour force participating in study towards an educational qualification did so for reasons of 
'further training or qualifications'. A combination of one or more of 'improve job skills', 'get a job or a different job' and 'further training or qualifications' were selected by 95.1 percent of those studying towards an educational qualification.

The three most common reasons for participation in inhouse training were to 'improve job skills', 'further training or qualifications' and because the training was 'compulsory'. Most participants ( 99.4 percent or 339,400 people) undertook in-house training for at least one reason out of 'compulsory', 'improve job skills', and 'further training or qualifications'.

By definition, respondents who participated in external training did so to 'improve their job skills'. In addition to this, the most common reason for participation in external training was to do 'further training or qualifications'. It is interesting to note that just 3.6 percent of external training participants undertook training to 'get a pay rise'. This compares to 9.9 percent and 4.2 percent for education and inhouse training respectively.

All respondents, regardless of whether they participated in education or training, were asked about their expected labour market and training outcomes in the next 12 -months. The idea behind this question was to see if there were differences in expectations between those who did and did not participate. 'Further training or qualifications' were selected by 545,200 people, or 72.5 percent of those who had participated in education and or training in the previous year, while 473,600 people thought education and training would 'improve their job skills'. In comparison, for those who did not participate in education and training, just 18.0 percent $(458,200$ people) thought that they would 'improve job skills' in the next 12-months.

\section{Gross flows}

The HLFS was not designed to be a longitudinal survey however, because respondents are in the survey for eight consecutive quarters, it is possible to conduct some longitudinal gross flows analysis of those who participated in the ETS. The analysis presented here followed ETS respondents from September 1996 to March 1997. This analysis provides some indicative results bearing in mind the following caveats:

- It is possible that at the time respondents were interviewed, they may not have completed their education and training.

- The theoretical $6 / 8$ ths gross flows match between a September and a March quarter is never achieved because respondents leave the survey if they move house or die and enter the survey if they turn 15 . This means that the matched sample used for gross flows analysis is biased slightly.

- The March quarter used in this analysis is very seasonal, because of the large number of students working or looking for work at that time.
- The HLFS does not measure movement between jobs for people who are employed. Therefore it is not possible to measure if employed people changed their job as a result of participation in education and training.

Bearing these caveats in mind, the following gross flows analysis looks at the transition probabilities for two groups; those not employed (i.e. the unemployed and those not in the labour force) and the employed.

The probability of shifting from a state of not being employed to one of being employed was higher for those who had studied towards a qualification compared with those who had not studied in the previous year $(0.28$ versus 0.15 respectively). The probability for a male who had not studied for a qualification to move from being not employed to being employed was 0.19 . This compared with 0.33 for those who had studied towards a qualification. The same probabilities for females were 0.14 and 0.23 respectively.

In the case of external training, those who had participated had a 0.25 percent probability of moving from being not employed to being employed, while those who had not participated had a 0.17 percent probability of making the same transition. The probability of moving from not being employed to being employed was higher for both males and females as a result of participation in external training. The difference was more marked for females than males. For males the probability of moving into employment was 0.21 for those who had not participated, compared with 0.29 for those who had. For females the same probabilities were 0.15 and 0.23 respectively.

\section{Conclusion}

The information collected in the ETS has provided a valuable insight to the characteristics of education and training participants in the labour force (and the working-age population). From this analysis we know that nearly half of the New Zealand labour force participated in some form of education and training in the year to September 1996.

Those who participated in education were very different to those who participated in training. The former tend to be young, working part-time, have less history with their employer and are earning less. The latter tend to be older, more established in their jobs, have been with their employer for five years or more and on a relatively higher salary.

These characteristics are reflected in the barriers and support for education and training which showed that those studying towards an educational qualification were more likely to indicate that they had experienced some difficulty. 'Time' and 'cost' proved to be the biggest barriers in this case.

\section{Future research}

The Education and Training Survey was a one-off survey conducted by Statistics New Zealand. While it provided a large amount of useful information, there are no further 
surveys planned. The Longitudinal Survey of Income Dynamics, currently in the development stages within Statistics New Zealand, may provide information on educational qualifications, and changes in educational qualifications, if it carries through to implementation phase.

Further study on the long-term effects of education and training on individuals would be valuable. In the case of education, this should be possible through the Longitudinal Survey. Unfortunately, the Longitudinal Survey will not cover training - leaving an information gap on topics such as participation rates, the characteristics of participants, outcomes from training and changes trends over time.

\section{Notes}

1. OECD Economic Surveys New Zealand 1996. OECD 1996 Paris.

2. Ministry of Education Tertiary Education Review September 1997.

3. Lynch LM FRBNY Economic Policy Review January 1995.

4. Labour force status refers to whether an individual is employed, unemployed or not in the labour force.

5. The author gratefully acknowledges the support of Peter McMillen for his work on the logistic regressions used in this section.

\section{References}

Australian Bureau of Statistics. (1994) Training and education experience in Australia 1993. Canberra: Australian Bureau of Statistics

Bassi, L., Cheney, S. and Van Buren M. (1997) Training industry trends 1997, Training and Development. November:46-59

Betts, J. (1998) The impact of educational standards on the level and distribution of earnings, The American Economic Review, 88(1):266-275

Callister, P. (1992) Strategies for monitoring industry training effort and outcomes in New Zealand. Wellington: Ministry of Education

Darrah, C. (1995) Workplace training, workplace learning: a case study, Human Organization, 54(1):3139

Dockery, A., Norris, K. and Stromback, T. (1998) The social return to apprenticeship training, The Australian Economic Review, 31(1):37-46

Department of Statistics (1989) Report of the review committee on labour and employment statistics. Wellington, Department of Statistics

Frazis, H., Glittleman M., Horrigan M. and Joyce, M. (1998) Results from the 1995 Survey of Employerprovided training, Monthly Labor Review, June: 3-13

Gobbi, M. (1998) Participation on post-compulsory education and training in New Zealand, unpublished.
Hight, J. (1998) Young worker participation in post-school education and training, Monthly Labor Review, June:14-21

Lynch, L. (1992) Private-sector training and the earnings of young workers, The American Economics Review, March:299-312

Lynch, L. (1995) The growing wage gap: is training the answer?, FRBYN Economic Policy Review, January: $54-58$

Manni, A. (1998) Income Returns to Higher Education in New Zealand Over Time: 1981 - 1996, paper presented at the New Zealand Association of Economists Conference, Wellington September 2-4

New Zealand Government (1997) A Future Qualifications Policy for New Zealand (the Green papers) - A Plan for the National Qualifications Framework, Overview, Tertiary Education Review. Wellington: Ministry of Education

OECD (1996) Economic surveys: New Zealand 1996. OECD, Paris

Prime Ministerial Taskforce on Employment (1994) Employment - The Issues, Facing New Zealand's Biggest Challenge, Understanding New Zealand's Biggest Challenge: Summary of Consultations, Addressing New Zealand's Biggest Change: Proposals for Action

Rose, D. (1992) A review of labour market statistics. Wellington: Statistics New Zealand

Shipley, L., Couillard R., Rogers, A. and Ying Dai, S. (1997) Adult education and training in Canada. Statistics Canada

Simpson, D. (1998) Where has all the talent gone?, Otago/ Southland Employers Association inc, August: 13

Statistics New Zealand (1994) Labour Market Annual Volume. Wellington: Statistics New Zealand

Statistics New Zealand (1995) Labour Market Annual Volume. Wellington: Statistics New Zealand

Sturrock, F. (1995) Industry Training and Pre-employment Programmes in New Zealand. Ministry of Education: Wellington

Walker, M., Udy, K., Pole, N. (1997) Adult Literacy in New Zealand - Results of the International Adult Literacy Survey. Wellington: Ministry of Education

Ward, T. (1998) In-house training - the cost effective solution, The Employer, August:10

\section{Author}

Raewyn O'Neill is an Analyst at Regional Statistics, Statistics New Zealand,

Po Box 2922,

Wellington.

E-mail: raewyn_o'neill@stats.govt.nz 